\title{
Replacing maize grain with dried citrus pulp in a concentrate feed for Jersey cows grazing ryegrass pasture
}

\author{
L. Steyn ${ }^{1 \#, \text { R. Meeske }}{ }^{1,2} \&$ C.W. Cruywagen ${ }^{1}$ \\ ${ }^{1}$ Department of Animal Sciences, Stellenbosch University, Private Box X1, Matieland 7602, South Africa \\ ${ }^{2}$ Directorate: Animal Sciences, Department of Agriculture Western Cape, Outeniqua Research Farm, P.O. Box 249, \\ George, 6530, South Africa
}

(Received 21 April 2017; Accepted 2 June 2017; First published online 6 July 2017)

Copyright resides with the authors in terms of the Creative Commons Attribution 4.0 South African License.

See: http://creativecommons.org/licenses/by/4.0/za

Condition of use: The user may copy, distribute, transmit and adapt the work, but must recognize the authors and the South African Journal of Animal Science.

\begin{abstract}
Dried citrus pulp (DCP) is a high-fibre by-product of the citrus industry. In total mixed ration (TMR) systems it has been shown to maintain a more stable ruminal environment, improving overall production compared with maize. The aim of the study was to determine the effects of stepwise replacement of maize with DCP in a concentrate supplement on milk yield, milk composition and rumen health of Jersey cows grazing ryegrass pasture. Sixty-eight lactating Jersey cows $(\mu \pm$ SD; $84.5 \pm 43.8$ days in milk, $20.4 \pm 3.09$ $\mathrm{kg} /$ day) were used in the trial. Cows were allocated to one of four treatments, with 17 cows per treatment, namely no DCP (NDCP): 0\% replacement; low DCP (LDCP): 33\% replacement; medium DCP (MDCP): $66 \%$ replacement; and high DCP (HDCP): 100\% replacement. An additional six ruminally cannulated Jersey cows were randomly allocated to the NDCP and HDCP treatments in a two-period cross-over design. Milk yield decreased between 2.1 and $3.2 \mathrm{~kg} /$ day when maize was replaced with DCP. Milk fat content did not differ between treatments. However, treatment had a quadratic effect on milk protein and lactose content, with the LDCP and MDCP treatments having the highest values. No change in the diurnal ruminal pH curve and no differences in the rate and extent of pasture dry matter and neutral detergent fibre degradability between treatments were observed. In conclusion, replacing maize grain with DCP in a conventional concentrate diet led to a decrease in milk yield, while rumen health was maintained.
\end{abstract}

Keywords: Fruit waste, maize alternatives, pasture degradability, starch, supplementation

\#Corresponding author: lobkes@elsenburg.com

\section{Introduction}

In pasture-based dairy systems, the use of supplemental concentrate feeding is essential to maximizing milk production from pasture. Cereal grains form the largest part of the concentrate supplement, and play an important role in determining the profitability of a dairy farm (Allen \& Knowlton, 1995; NRC, 2001). The high starch content of cereal grains has a limiting effect on microbial activity in the rumen owing to lactic acid production, resulting in low ruminal pH (Calsamiglia et al., 2010; Poulsen et al., 2012; Jacobs, 2014). This affects fibre degradation and has negative production implications. Despite the problems associated with feeding starches, it is practised widely because of the high energy content, which promotes milk production. Other non-fibre carbohydrates such as sugar and pectin (prevalent in various fruit wastes) have a more positive effect on the rumen environment (Hall \& Herejk, 2001; Ribeiro et al., 2005) and maintain production when replaced in TMR systems (Leiva et al., 2000; Broderick et al., 2008). Dried citrus pulp is a by-product of the juicing industry (Bampidis \& Robinson, 2006) and is high in sugar (208 g/kg dry matter (DM)) and pectin (150-200 g/kg DM) and low in starch (174 g/kg DM) (Miller-Webster \& Hoover, 1998; Hindrichsen et al., 2004). The inclusion of DCP in dairy rations is common practice in TMR systems, where it acts as a flavour enhancer owing to the high sugar content, promoting feed intake (Bampidis \& Robinson, 2006; Penner \& Oba, 2009; Oba, 2011). No previous work has been documented on the use of DCP as a feed source for cows grazing pasture. Citrus pulp is a seasonal feed source. However, there is merit in investigating its use in South Africa as it could offer an alternative to maize when the maize cost is high. Citrus pulp is often used as is, but in dried form it can be stored long term, forming an integral part of 
the annual feeding plan of a farm. The aim of the study was therefore to determine how effectively maize could be replaced with DCP in a concentrate supplement fed to Jersey cows grazing annual ryegrass pasture and the possible rumen health implications.

\section{Materials and methods}

The trial was carried out at Outeniqua Research Farm, George, South Africa (22 $25^{\prime} 16^{\prime \prime} \mathrm{E}$ and $33^{\circ}$ $58^{\prime} 38^{\prime \prime}$ S) in early spring, that is, September to November 2013. The mean minimum and maximum temperatures were $11.7^{\circ} \mathrm{C}$ and $21.5^{\circ} \mathrm{C}$, respectively, and the total rainfall during the trial period was 295 $\mathrm{mm}$ (ARC, 2013). Kikuyu pasture (Pennisetum clandestinum) had been over-sown with annual Italian ryegrass (Lolium multiflorum var. Italicum, cv. Jeanne) on an 8.6 ha area under permanent irrigation in the previous autumn. An Aitchison seeder was used at a rate of $18 \mathrm{~kg} / \mathrm{ha}$. The area was characterized by Witfontein soil form (Swanepoel et al., 2013) and paddocks were fertilized with $42 \mathrm{~kg} \mathrm{~N} / \mathrm{ha}$ using limestone ammonium nitrate $(280 \mathrm{~g} \mathrm{~N} / \mathrm{kg})$ after each grazing. Ethical clearance was obtained through the Western Cape Department of Agriculture, South Africa (clearance number R13/83). Experimental treatments were defined according to the level of maize in the concentrate supplement that was replaced by DCP. No DCP (NDCP) denotes $0 \%$ replacement; low DCP (LDCP) denotes 33\% replacement; medium DCP (MDCP) denotes $66 \%$ replacement; and high DCP (HDCP) denotes 100\% replacement. The ingredient composition of the four concentrate supplements is shown in Table 1.

Table 1 Ingredient composition $(\mathrm{g} / \mathrm{kg})$ of four concentrate supplements fed to 68 Jersey cows grazing ryegrass pasture

\begin{tabular}{lcccc}
\hline \multirow{2}{*}{ Parameter } & \multicolumn{4}{c}{ Treatment $^{\star}$} \\
\cline { 2 - 5 } & NDCP & LDCP & MDCP & HDCP \\
\cline { 2 - 5 } Ground maize & 750 & 500 & 250 & 0 \\
Dried citrus pulp & 0 & 250 & 500 & 750 \\
Soybean oilcake & 76 & 98 & 121 & 149 \\
Wheat bran & 94 & 81 & 67 & 38 \\
Molasses (liquid) & 40 & 40 & 40 & 40 \\
Feed lime & 20 & 10 & 0 & 0 \\
Salt & 10 & 10 & 10 & 10 \\
Premix* & 5 & 5 & 5 & 5 \\
MgO & 3 & 3 & 3 & 3 \\
Mono-CaP & 2 & 3 & 4 & 5 \\
\hline
\end{tabular}

* NDCP: no dried citrus pulp, $0 \%$ replacement; LDCP: low dried citrus pulp, $33 \%$ replacement; MDCP: medium dried citrus pulp, $66 \%$ replacement; HDCP: high dried citrus pulp, $100 \%$ replacement

** Premix: 4 mg/kg Cu; 10 mg/kg Mn; 20 mg/kg Zn; 0.34 mg/kg I; 0.2 mg/kg Co; 0.06 mg/kg Se; 6 x $10^{6}$ IU vitamin A; 1 x $10^{6} \mathrm{IU}$ vitamin $\mathrm{D}_{3} ; 8 \times 10^{3} \mathrm{IU}$ vitamin $\mathrm{E}$

The trial consisted of two components, namely the production study and the rumen metabolism study, which ran concurrently. The production study consisted of 68 lactating Jersey cows, which were blocked according to the average milk yield of the three weeks preceding the trial ( $\mu \pm$ SD; $20.4 \pm 3.1 \mathrm{~kg} /$ day), days in milk ( $84.5 \pm 43.8$ days), and lactation number $(4.5 \pm 2.4)$. Cows in blocks were then assigned to treatments according to a complete randomized block design for a continuous lactation trial over 51 days. The rumen metabolism study consisted of six ruminally cannulated cows that were randomly allocated between the NDCP and HDCP treatments and subjected to a two-period cross-over design. A 14-day adaptation period was implemented after each cross-over, before rumen data collection commenced. Cows in both the production study and the rumen metabolism study received $6 \mathrm{~kg} \mathrm{DM} /$ day of the concentrate supplement, which was fed over two sessions, during the morning and afternoon milking. The area used for grazing was divided into $35 \times 0.25$ ha paddocks, with an average grazing interval of 24 days. A rising plate meter (RPM) (Jenquip, Reid Line East, RD5, Feilding, New Zealand, 4775) was used to determine pasture height per paddock one day prior to grazing (Table 2). Pasture yield could then be estimated and allocated to cows by means of strip grazing. All cows grazed together, and water was available ad libitum in the pasture camps. 
Cows were milked twice daily at 05:30 and 13:30, and milk yield was automatically recorded at each milking using a Dairy Master swing-over milking machine. Composite samples of the morning and afternoon milking sessions were collected once every second week, preserved with Bronopol, and analysed for fat, protein, lactose, milk urea nitrogen (MUN), somatic cell count (SCC) and pH with FOSS CombiFoss ${ }^{\mathrm{TM}}{ }^{\mathrm{FT}}+$ milk analyser (FOSS, Foss Allè 1, DK-3400 Hillerød, Denmark). The $4 \%$ fat corrected milk (FCM) yield was determined using the Gaines formula (Gaines, 1928), in which $4 \% \mathrm{FCM}=\left(0.4^{*} \mathrm{~kg}\right.$ milk $)+\left(15^{*} \mathrm{~kg}\right.$ fat $)$ to correct milk yield to a constant energy basis. Cows were weighed and scored at the commencement and completion of the trial. Bodyweight (BW) was recorded over two days, and the average was used to compensate for possible differences owing to defecation, urination and water intake. Body condition scoring (BCS) was performed using the five-point scale described by Wildman et al. (1982) and Edmonson et al. (1989), in which a score of 1 indicates an extremely thin cow and 5 indicates an extremely fat cow. Average daily gain (ADG) was calculated as the weight difference obtained over 51 days.

Table 2 Mean $( \pm S D)$ of the pre- and post-grazing rising plate meter height, pasture yield, pasture allowance and pasture intake determined using the seasonal linear regression

\begin{tabular}{lc}
\hline Parameter $^{*}$ & Pasture values \\
\hline Pre-grazing & \\
RPM height $(1$ unit $=5 \mathrm{~mm})$ & $42.2 \pm 8.93$ \\
Pasture yield $(\mathrm{kg} \mathrm{DM} / \mathrm{ha})^{* *}$ & $3640 \pm 814$ \\
Pasture allowance $(\mathrm{kg} \mathrm{DM} /$ cow/day) & $11.2 \pm 2.00$ \\
Post grazing & \\
RPM height $(1$ unit $=5 \mathrm{~mm})$ & $13.0 \pm 2.35$ \\
Pasture yield $(\mathrm{kg} \mathrm{DM} / \mathrm{ha})$ & $987 \pm 214$ \\
Estimated pasture intake $(\mathrm{kg} /$ cow/day) & $10.6 \pm 1.85$ \\
\hline
\end{tabular}

${ }^{*} \mathrm{RPM}$ : rising plate meter; DM: dry matter

${ }^{* *} Y=91.06^{\star} H-200.59$, where $Y=$ DM yield and $H=$ RPM reading (Steyn, 2012)

TruTrack pH data loggers (Model pH-HR Mark 4, Intech Instruments Ltd, New Zealand) were used to record the diurnal fluctuations of ruminal $\mathrm{pH}$ every 10 minutes, over a 72-hour period. Loggers were carefully calibrated with two buffer solutions ( $\mathrm{pH} 4$ and 9 ) before insertion into the rumen. Rumen fluid samples were collected from ruminally cannulated cows at six-hour intervals (08:00, 14:00, 20:00 and 02:00) to analyse ammonia nitrogen $\left(\mathrm{NH}_{3}-\mathrm{N}\right)$ (Broderick \& Kang, 1980) and volatile fatty acids (VFA) (Siegfried et al., 1984). Samples were collected with a hand-held suction pump. After collection, samples were filtered through four layers of cheesecloth. Aliquots were then frozen at $-20^{\circ} \mathrm{C}$ in small airtight containers until further analysis. Pasture DM and neutral detergent fibre (NDF) degradability were determined through the use of in situ Ankom dacron bags $(10 \times 20 \mathrm{~cm})$, with a nominal average pore size of $53 \mu \mathrm{m}$, containing dried and cut $(5$ $\mathrm{mm}$ ) pasture samples. Seventeen bags were prepared for each cow, and bags were incubated for 2, 4, 8 , 16, 30, 72 and 96 hours. Pasture residue in bags was analysed for DM (AOAC, 2002; method 934.01) and NDF (Robertson \& Van Soest, 1981) using the Ankom fibre analysis system (71 Ramachandra Agrahara, Azad Nagar, Chamarajpet, Bangalore, 560 018). Pasture DM and NDF degradability were determined with the equation:

$$
p=a+b\left(1-e^{-c t}\right)
$$

Where: $p=$ actual degradation at time $\mathrm{t}$

$a=$ intercept of degradation curve at $t=0$

$b=$ potential degradability of component

$\mathrm{e}=$ the base of natural logarithms

$c=$ rate constant for degradation of coefficient $b$ (Ørskov \& McDonald, 1979) 
Pasture and feed samples were collected once every second week, dried, and analysed for DM, organic matter (OM) (AOAC, 2002) (Method 942.05), crude protein (CP) (AOAC, 2002) (Method 990.03, using Leco N analyser, model FP 528), NDF (Robertson \& Van Soest, 1981) (using the Ankom fibre analysis system with heat stable $\alpha$-amylase followed by incineration of the residue), acid detergent fibre (ADF) (Robertson \& Van Soest, 1981) (using the Ankom fibre analysis system, followed by incineration of the residue), neutral detergent insoluble nitrogen (NDIN) (NDF procedure, residue analysed for CP), acid detergent insoluble fibre (ADIN) (ADF procedure, residue analysed for CP), ether extract (EE) (AOAC, 2002) (Method 920.39), gross energy (GE) (MC 1000 Modular Calorimeter, Energy Instrumentation, Sandton, South Africa, 2146), in vitro organic matter degradability (IVOMD) (Buys et al., 1996), ), Ca (ALASA, 1998) (Method 6.1.1) and P (ALASA, 1998) (Method 6.1.1). Metabolizable energy (ME) was calculated with the equation of Robinson et al. (2004):

$$
\mathrm{ME}(\mathrm{MJ} / \mathrm{kg} \mathrm{DM})=\mathrm{GE} \times \mathrm{IVOMD} \times 0.82 \text { (Robinson et al., 2004). }
$$

The NFC content was calculated as follows:

$$
\mathrm{NFC}(\mathrm{g} / \mathrm{kg} \mathrm{DM})=100-(\mathrm{NDF}+\mathrm{CP}+\mathrm{EE}+\mathrm{ash})(\mathrm{NRC}, 2001) .
$$

Milk yield, milk composition, BW and BCS data were subjected to a mixed model procedure, using SAS version 9.2 (SAS, 2008). Orthogonal contrasts were used to test for the linear, quadratic and cubic effects of replacing maize with DCP at increasing levels. Covariance was not included because of the blocking of cows between treatments, which was expected to minimize variation based on animal factors. VFA and $\mathrm{NH}_{3}-\mathrm{N}$ data were analysed using a mixed model procedure over time. The in situ Dacron bag study was subjected to a main effects ANOVA. The data were fitted to the non-linear model, $p=a+b(1-$ $e^{-c t}$ ), using an iterative regression analysis to determine the constants $a, b$ and $c$ (Ørskov \& McDonald, 1979). The ruminal $\mathrm{pH}$ data were subjected to a repeated measures ANOVA. Tukey's test was used to compare the treatment means at $5 \%$ significance level. The null hypothesis was Ho: $\mu 1=\mu 2=\mu 3=\mu$ a. It was rejected where $P<0.05$ and a trend was identified in which $0.05<P<0.10$. Least squares means were used to calculate a pooled standard error of treatment means. Shapiro-Wilk tests were used to test for normality (Shapiro \& Wilk, 1965).

\section{Results}

The HDCP concentrate supplement had a higher inclusion of soybean oilcake to compensate for the low CP content of the DCP. All four concentrate supplements were formulated to be iso-nitrogenous, although the final products differed slightly (Table 3). The level of mono-CaP had to be raised as the level of DCP increased to counteract the high $\mathrm{Ca}$ content of $\mathrm{DCP}$, thus maintaining the $\mathrm{Ca}: \mathrm{P}$ ratio. The same applies to the feed lime, which was highest in the NDCP concentrate supplement. The NDCP concentrate supplement had the highest NFC content and consequently the lowest NDF content. The ME content was similar in all concentrate supplements. Daily pasture intake was estimated at $10.6 \mathrm{~kg} \mathrm{DM} / \mathrm{cow}$, calculated as the difference in pasture yield before and after grazing, $3640 \mathrm{~kg} \mathrm{DM} / \mathrm{ha}$ and $987 \mathrm{~kg} \mathrm{DM} / \mathrm{ha}$, respectively (Table 2). Pasture was grazed to an average of 13 on the RPM, which is slightly under-grazed. A reading of 10-12 on the RPM is indicative of well grazed pasture (Irvine et al., 2010). However, 13 on the RPM is not extreme and would imply that the animals received enough pasture.

The inclusion of DCP in the rations, at the expense of maize, resulted in a linear decrease in milk yield and $4 \%$ FCM yield (Table 4). The decreases in milk yield for a 33, 66, and 100\% replacement of maize with DCP compared with $0 \%$ replacement were $2.13,2.27$, and $3.23 \mathrm{~kg} /$ day, respectively. Differences in milk yield between the LDCP, MDCP and HDCP treatments were not significant. Treatment did not have an effect on milk fat content or SCC. The replacement of maize had a quadratic effect on protein and lactose content $(P$ $=0.011$ and 0.035 , respectively). The initial replacement of maize with DCP, namely $33 \%$ and $66 \%$, resulted in an increase in protein and lactose content, then these two parameters decreased again. The MUN content of milk increased linearly with as the DCP inclusion level increased $(P=0.023)$. Treatment had a linear effect on fat and protein yield $(P<0.001)$, which decreased as the level of maize replaced with DCP increased. No linear, quadratic or cubic effects were observed for BW, ADG and BCS change. 
Table 3 Chemical composition ( $/ \mathrm{kg} \mathrm{DM}$; mean $\pm \mathrm{SD}$ ) of four concentrate supplements, dried citrus pulp used in the supplements and ryegrass pasture $(n=5)$

\begin{tabular}{|c|c|c|c|c|c|c|}
\hline \multirow{2}{*}{ Parameter } & \multicolumn{4}{|c|}{ Treatment $^{\star \star}$} & \multirow{2}{*}{ DCP } & \multirow{2}{*}{ Pasture $^{\star \star \star}$} \\
\hline & NDCP & LDCP & MDCP & HDCP & & \\
\hline DM & $892 \pm 6.42$ & $889 \pm 8.12$ & $894 \pm 5.70$ & $902 \pm 8.72$ & $870 \pm 33.2$ & $158 \pm 21.0$ \\
\hline OM & $935 \pm 1.47$ & $930 \pm 1.44$ & $912 \pm 3.46$ & $894 \pm 1.21$ & $919 \pm 3.58$ & $884 \pm 13.8$ \\
\hline $\mathrm{CP}$ & $117 \pm 1.30$ & $120 \pm 2.91$ & $117 \pm 2.40$ & $121 \pm 2.42$ & $48.1 \pm 1.67$ & $174 \pm 26.2$ \\
\hline $\mathrm{EE}$ & $27.9 \pm 6.14$ & $26.8 \pm 3.45$ & $23.5 \pm 2.98$ & $18.1 \pm 2.48$ & $16.9 \pm 2.04$ & $41.5 \pm 1.96$ \\
\hline NFC & $671 \pm 15.6$ & $607 \pm 24.9$ & $609 \pm 14.5$ & $581 \pm 6.41$ & $653 \pm 3.08$ & $231 \pm 54.1$ \\
\hline NDF & $119 \pm 20.0$ & $168 \pm 24.8$ & $162 \pm 12.2$ & $174 \pm 3.04$ & $201 \pm 7.02$ & $438 \pm 18.6$ \\
\hline ADF & $39.7 \pm 3.34$ & $96.5 \pm 7.99$ & $147 \pm 4.48$ & $198 \pm 9.45$ & $257 \pm 14.2$ & $298 \pm 10.0$ \\
\hline NDIN & $5.86 \pm 0.94$ & $6.81 \pm 1.30$ & $8.01 \pm 0.50$ & $9.09 \pm 0.20$ & $7.45 \pm 0.65$ & $10.6 \pm 2.23$ \\
\hline ADIN & $16.2 \pm 4.72$ & $8.02 \pm 1.53$ & $6.27 \pm 0.66$ & $5.21 \pm 0.53$ & $3.46 \pm 0.32$ & $5.15 \pm 2.08$ \\
\hline IVOMD & $976 \pm 29.7$ & $980 \pm 41.6$ & $994 \pm 30.7$ & $993 \pm 30.8$ & $987 \pm 5.37$ & $872 \pm 11.8$ \\
\hline GE (MJ/kg DM) & $17.1 \pm 0.86$ & $17.1 \pm 1.01$ & $16.6 \pm 0.67$ & $16.2 \pm 1.15$ & $16.0 \pm 0.11$ & $17.3 \pm 0.88$ \\
\hline ME (MJ/kg DM) & $14.0 \pm 3.61$ & $14.0 \pm 5.20$ & $13.9 \pm 3.74$ & $13.5 \pm 3.29$ & $13.2 \pm 0.02$ & $12.7 \pm 1.38$ \\
\hline $\mathrm{Ca}$ & $11.3 \pm 0.17$ & $13.1 \pm 0.49$ & $19.4 \pm 6.22$ & $25.2 \pm 8.90$ & $15.3 \pm 1.53$ & $3.91 \pm 0.47$ \\
\hline $\mathrm{P}$ & $5.01 \pm 0.08$ & $4.72 \pm 0.15$ & $4.37 \pm 0.11$ & $4.31 \pm 0.20$ & $1.27 \pm 0.21$ & $5.61 \pm 0.60$ \\
\hline $\mathrm{Mg}$ & $3.62 \pm 0.16$ & $3.39 \pm 0.20$ & $3.32 \pm 0.05$ & $3.28 \pm 0.17$ & $1.21 \pm 0.04$ & $3.31 \pm 0.21$ \\
\hline $\mathrm{K}$ & $9.4 \pm 0.17$ & $10.9 \pm 0.32$ & $12.6 \pm 0.17$ & $14.5 \pm 0.22$ & $9.59 \pm 0.37$ & $36.0 \pm 12.5$ \\
\hline
\end{tabular}

* DM: dry matter; OM: organic matter; CP: crude protein; EE: ether extract; NFC: non-fibrous carbohydrates; NDF: insoluble nitrogen; IVOMD: in vitro organic matter degradability; GE: gross energy; ME: metabolizable energy

** NDCP: no dried citrus pulp, $0 \%$ replacement; LDCP: low dried citrus pulp, 33\% replacement; MDCP: medium dried citrus pulp, 66\% replacement; HDCP: High dried citrus pulp, 100\% replacement

${ }_{* \star \star}$ Pasture: annual Italian ryegrass (Lolium multiflorum, variety Italicum, cultivar Jeanne)

At 14:30 the ruminal $\mathrm{pH}$ of cows in the HDCP treatment reached a lower level $(P=0.04)$ than that of those in the NDCP treatment, that is, $\mathrm{pH} 5.95$ and $\mathrm{pH} 6.20$, respectively (Figure 1). No other differences in $\mathrm{pH}$ were observed over the 24-hour period. A sudden sharp decrease in ruminal $\mathrm{pH}$ was observed between 05:30 and 06:30 and between 13:30 and 14:30, which corresponded with consumption of the concentrate supplement in the milking parlour. Treatment did not have an effect on daily mean ruminal $\mathrm{pH}$ (Table 5). There were no differences in the duration of the ruminal $\mathrm{pH}$ below $\mathrm{pH} 6.2, \mathrm{pH} 6.0$ and $\mathrm{pH}$ 5.8. No difference was found in the total VFA concentration between cows in the NDCP and HDCP treatments (Table 5). The molar proportion of acetate, propionate, butyrate and valerate and the acetate : propionate ratio remained unchanged. Isobutyrate $(P=0.04)$ and isovalerate $(P=0.02)$ concentrations were higher for cows in the NDCP treatment. The ruminal $\mathrm{NH}_{3}-\mathrm{N}$ concentration was higher $(P<0.01)$ for cows fed the HDCP concentrate supplement than cows fed the NDCP concentrate supplement at 02:00, 14:00 and 20:00 (Figure 2). No difference in ruminal $\mathrm{NH}_{3}-\mathrm{N}$ concentration was observed at 08:00. There were no differences in the degradability of pasture DM and NDF at any of the incubation times (Figures 3 and 4). All degradability parameters were the same for cows in the NDCP treatment and those in the HDCP treatment (Table 5). 
Table 4 Mean milk yield, milk composition, bodyweight and body condition score changes of cows receiving one of four concentrate supplements $(n=17)$

\begin{tabular}{|c|c|c|c|c|c|c|c|c|}
\hline \multirow{2}{*}{ Parameter } & \multicolumn{4}{|c|}{ Treatment $^{\star \star}$} & \multirow{2}{*}{ SEM } & \multirow{2}{*}{ Linear } & \multirow{2}{*}{ Quadratic } & \multirow{2}{*}{ Cubic } \\
\hline & NDCP & LDCP & MDCP & HDCP & & & & \\
\hline Milk yield (kg/cow) & $21.1^{\mathrm{a}}$ & $19.0^{\mathrm{b}}$ & $18.9^{\mathrm{b}}$ & $17.9^{\mathrm{b}}$ & 0.57 & $<0.001$ & 0.140 & 0.110 \\
\hline $4 \%$ FCM yield (kg/cow) & $22.5^{\mathrm{a}}$ & $20.3^{\mathrm{b}}$ & $20.0^{\mathrm{b}}$ & $19.4^{\mathrm{b}}$ & 0.55 & $<0.001$ & 0.103 & 0.272 \\
\hline Fat $(\mathrm{g} / \mathrm{kg})$ & 44.8 & 44.9 & 44.5 & 45.6 & 1.13 & 0.685 & 0.616 & 0.716 \\
\hline Protein $(\mathrm{g} / \mathrm{kg})$ & $34.9^{\mathrm{ab}}$ & $35.8^{\mathrm{a}}$ & $35.6^{\mathrm{a}}$ & $34.4^{\mathrm{b}}$ & 0.56 & 0.352 & 0.011 & 0.956 \\
\hline Lactose (g/kg) & $46.5^{\mathrm{a}}$ & $47.0^{\mathrm{a}}$ & $47.0^{\mathrm{ab}}$ & $45.6^{\mathrm{b}}$ & 0.30 & 0.638 & 0.035 & 0.864 \\
\hline $\operatorname{SCC}\left(\times 10^{3}\right.$ cells $\left./ \mathrm{mL}\right)$ & 93.8 & 200 & 208 & 173 & 40.2 & 0.146 & 0.061 & 0.745 \\
\hline MUN (mg/dL) & $9.32^{\mathrm{a}}$ & $9.38^{a}$ & $10.3^{b c}$ & $10.1^{\mathrm{ac}}$ & 0.35 & 0.023 & 0.647 & 0.146 \\
\hline Fat yield (kg/cow) & $0.94^{\mathrm{a}}$ & $0.85^{\mathrm{b}}$ & $0.83^{b}$ & $0.81^{\mathrm{b}}$ & 0.02 & $<0.001$ & 0.149 & 0.480 \\
\hline Protein yield (kg/cow) & $0.73^{\mathrm{a}}$ & $0.68^{\mathrm{b}}$ & $0.67^{b}$ & $0.61^{\circ}$ & 0.02 & $<0.001$ & 0.909 & 0.204 \\
\hline BW before (kg) & 398 & 386 & 404 & 396 & 9.63 & 0.740 & 0.817 & 0.198 \\
\hline BW change $(\mathrm{kg})$ & +12.3 & +8.62 & +8.50 & +7.38 & 3.43 & 0.293 & 0.684 & 0.746 \\
\hline$A D G(k g / d)$ & 0.25 & 0.17 & 0.17 & 0.15 & 0.07 & 0.293 & 0.684 & 0.746 \\
\hline BCS before (scale 1-5) & 2.15 & 2.15 & 2.13 & 2.16 & 0.05 & 0.888 & 0.754 & 0.779 \\
\hline BCS change (scale 1-5) & +0.22 & +0.18 & +0.24 & +0.19 & 0.03 & 0.844 & 1.000 & 0.173 \\
\hline
\end{tabular}

${ }^{a, b}$ Row means with different superscripts differ significantly at $P<0.05$

* FCM: fat corrected milk; SCC: somatic cell count; MUN: milk urea nitrogen; BW: bodyweight; ADG: average daily gain; BCS: body condition score

${ }^{* *}$ NDCP: no dried citrus pulp, $0 \%$ replacement; LDCP: low dried citrus pulp, $33 \%$ replacement; MDCP: medium dried citrus pulp, $66 \%$ replacement; HDCP: high dried citrus pulp, $100 \%$ replacement

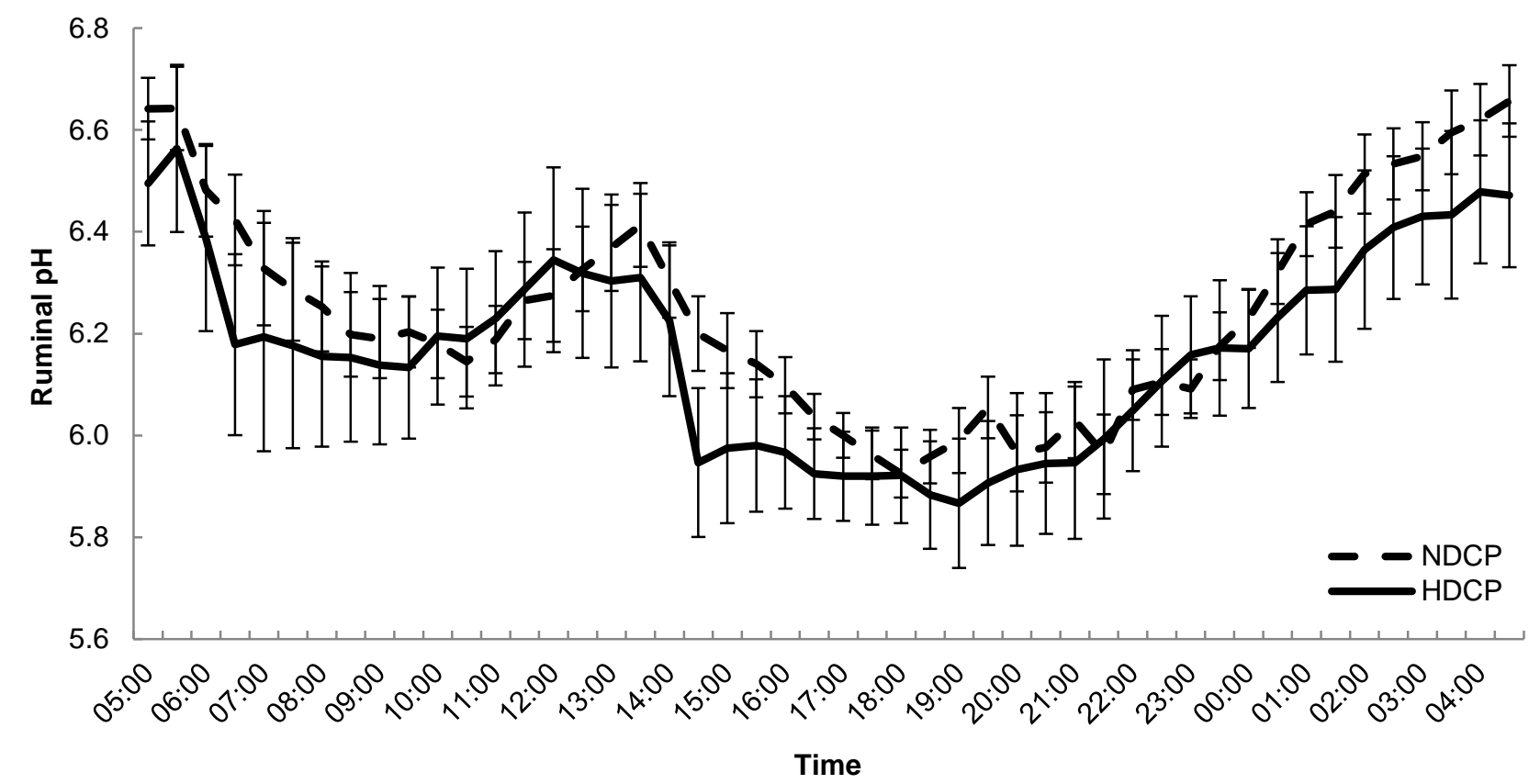

Figure 1 Diurnal fluctuations in ruminal $\mathrm{pH}$ of cows $(n=6)$ receiving various levels of dried citrus pulp and maize

Error bars represent SEM; NDCP: no dried citrus pulp, 0 \% replacement; HDCP: high dried citrus pulp, 100\% replacement 
Table 5 Ruminal pH parameters, fermentation products concentrations and ryegrass pasture degradability parameters $(n=6)$ of cows receiving various levels of dried citrus pulp and maize

\begin{tabular}{|c|c|c|c|c|}
\hline \multirow[t]{2}{*}{ Parameter $^{\star}$} & \multicolumn{2}{|c|}{ Treatment $^{\star \star}$} & \multirow[t]{2}{*}{ SEM } & \multirow[t]{2}{*}{ P-value } \\
\hline & NDCP & HDCP & & \\
\hline Mean pH & 6.25 & 6.17 & 0.061 & 0.389 \\
\hline \multicolumn{5}{|l|}{ Time below (hours) } \\
\hline $\mathrm{pH} 6.2$ & 11.5 & 12.3 & 1.919 & 0.789 \\
\hline pH 6.0 & 5.17 & 6.83 & 2.046 & 0.580 \\
\hline pH 5.8 & 1.25 & 2.75 & 1.095 & 0.361 \\
\hline Total VFA (mM) & 120 & 118 & 4.120 & 0.634 \\
\hline \multicolumn{5}{|l|}{$\mathrm{Mol} / 100 \mathrm{~mol}$} \\
\hline Acetate & 62.4 & 62.8 & 0.839 & 0.541 \\
\hline Propionate & 19.7 & 19.9 & 0.801 & 0.712 \\
\hline Butyrate & 15.2 & 14.8 & 0.521 & 0.682 \\
\hline Valerate & 1.17 & 1.13 & 0.059 & 0.398 \\
\hline Isobutyrate & 0.78 & 0.62 & 0.050 & 0.045 \\
\hline Isovalerate & 0.88 & 0.67 & 0.101 & 0.023 \\
\hline Acetate e: propionate & 3.19 & 3.18 & 0.166 & 0.931 \\
\hline $\mathrm{NH}_{3}-\mathrm{N}(\mathrm{mM} / \mathrm{L})$ & 7.49 & 14.7 & 0.885 & $<0.001$ \\
\hline \multicolumn{5}{|c|}{ Pasture degradability ${ }^{\star \star \star}$} \\
\hline \multirow[t]{3}{*}{ DM } & 20.4 & 20.7 & 0.374 & 0.602 \\
\hline & 68.4 & 68.4 & 0.746 & 0.984 \\
\hline & 0.06 & 0.06 & 0.001 & 0.756 \\
\hline NDF & 19.9 & 21.4 & 1.122 & 0.280 \\
\hline b & 72.9 & 70.6 & 1.791 & 0.264 \\
\hline c & 0.03 & 0.04 & 0.002 & 0.272 \\
\hline
\end{tabular}

${ }^{*}$ VFA: volatile fatty acids; NH3-N: ammonia nitrogen

** NDCP: no dried citrus pulp, $0 \%$ replacement; HDCP: high dried citrus pulp, $100 \%$ replacement

${ }^{* * *}$ Calculated with the equation $p=a+b(1-e-c t)$, where $a=$ intercept of degradation curve at $t=0 ; b=$ potential degradability of component; $c=$ rate constant for degradation of coefficient b (Ørskov \& McDonald, 1979)

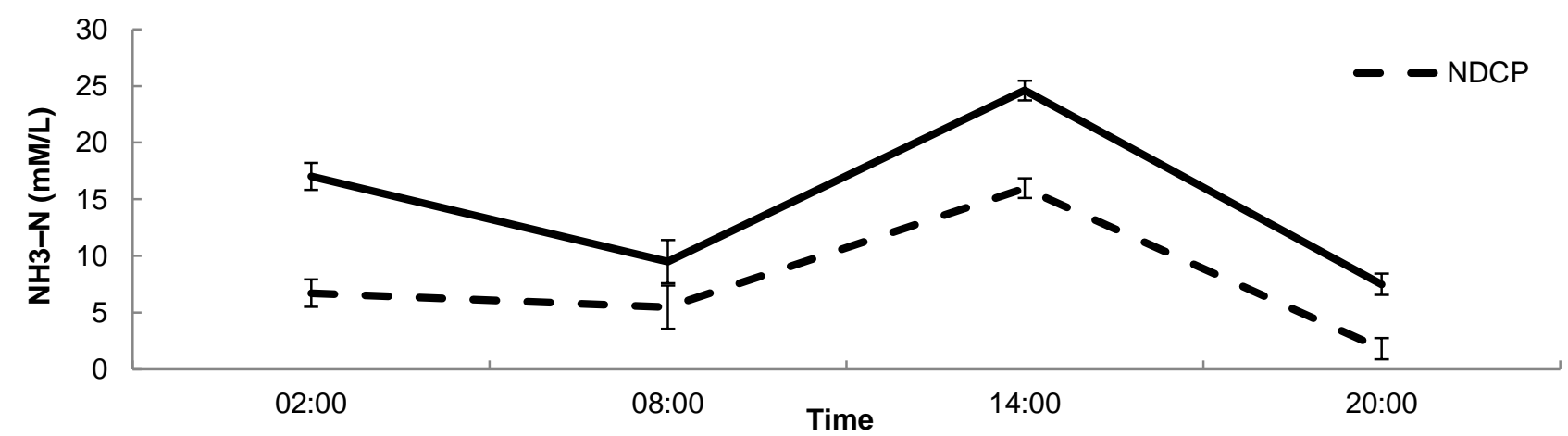

Figure 2 Fluctuations in ruminal $\mathrm{NH}_{3}-\mathrm{N}$ concentration at four sampling times of cows receiving various levels of dried citrus pulp and maize

Error bars represent SEM

NDCP: no dried citrus pulp, $0 \%$ replacement; HDCP: high dried citrus pulp, 100\% replacement 


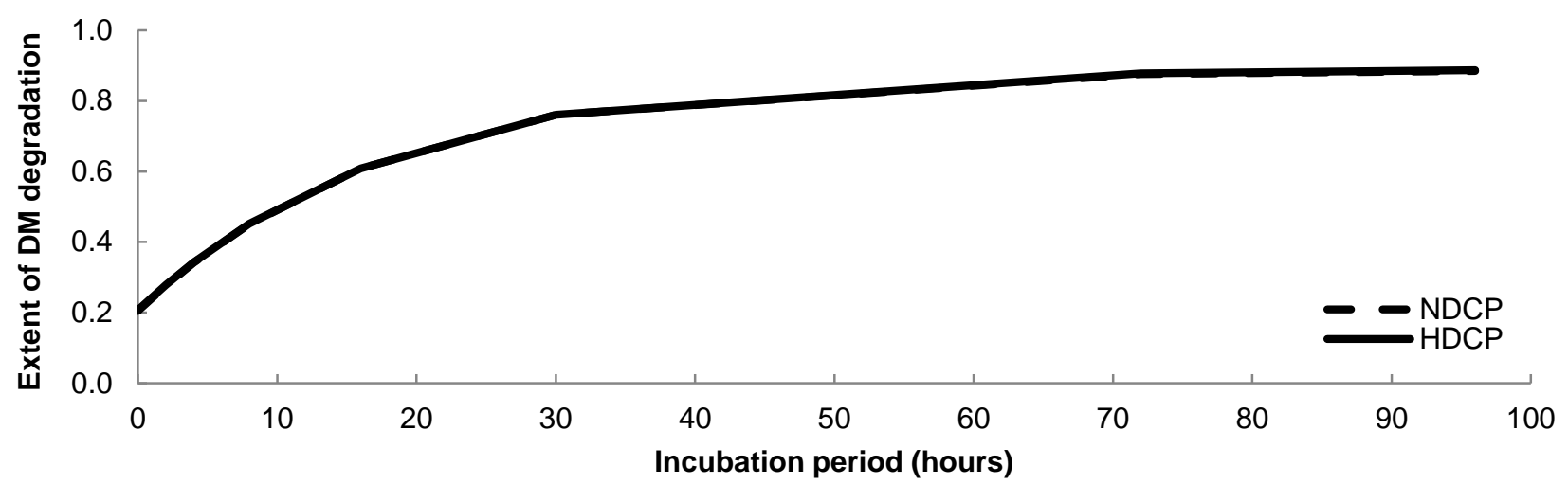

Figure 3 Extent of dry matter degradation in the rumen of cows receiving various levels of dried citrus pulp and maize over 96 hours of incubation

Error bars represent SEM

NDCP: no dried citrus pulp, $0 \%$ replacement; HDCP: high dried citrus pulp, 100\% replacement

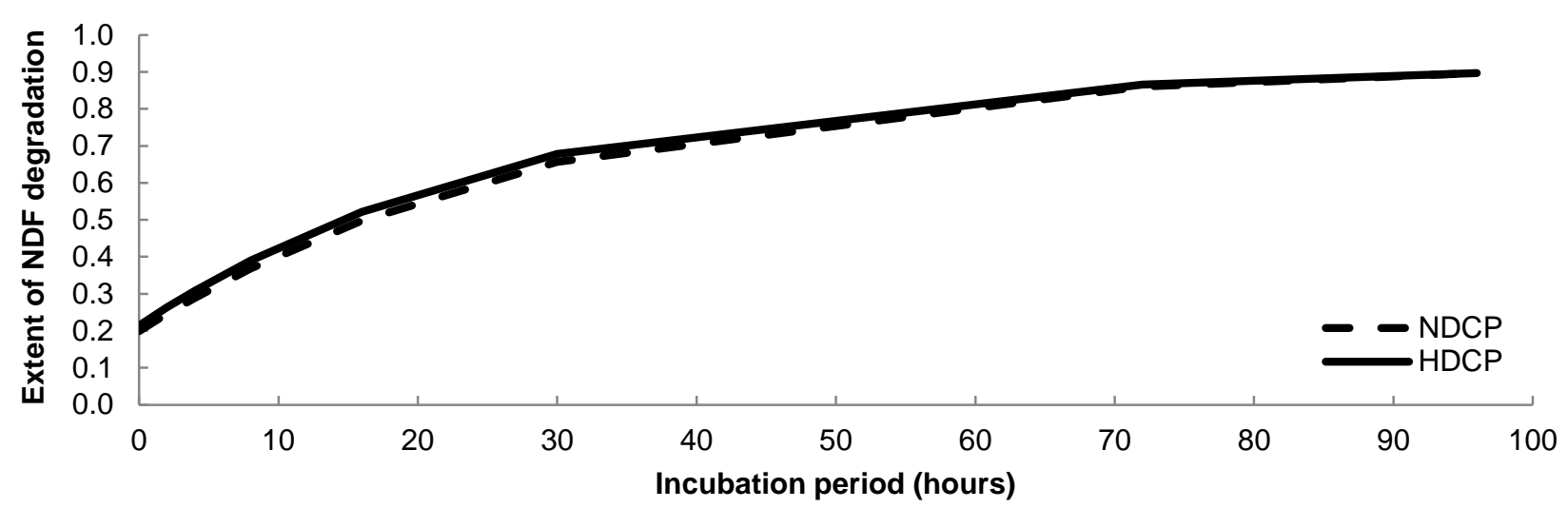

Figure 4 Extent of neutral detergent fibre degradation in the rumen of cows receiving various levels of dried citrus pulp and maize over 96 hours of incubation

Error bars represent SEM

NDCP: no dried citrus pulp, $0 \%$ replacement; HDCP: high dried citrus pulp, 100\% replacement

\section{Discussion}

All the diets offered similar ME intakes, although cows on the NDCP treatment yielded 2.13, 2.27 and $3.23 \mathrm{~kg} /$ day more milk than cows on the LDCP, MDCP and HDCP treatments, respectively. In various TMRbased trials, the level of starch was decreased by adding molasses or pure sucrose or by replacing hominy chop with citrus pulp (Leiva et al., 2000; Cherney et al., 2003; Broderick et al., 2008). However, no change in milk yield was found in any of these trials. It is possible that the higher NDF content of the LDCP, MDCP and HDCP concentrate supplements could limit pasture intake owing to rumen fill. However, individual pasture intake was not measured. Furthermore, in a study by Delahoy et al. (2003) the partial replacement of maize with beet pulp (NDF content $295 \mathrm{~g} / \mathrm{kg}$ DM) did not have an effect on pasture dry matter intake (DMI) and did not result in substitution for Holstein cows grazing orchardgrass (Dactylis glomerata). Similarly, Higgs et al. (2013) found no effect on pasture DMI when a high NDF supplement was fed (385 g/kg DM) to Friesian cows grazing perennial ryegrass (Lolium perenne). The results of these studies make the possibility of pasture substitution owing to higher NDF content seem unlikely.

An increase in milk fat was anticipated as maize was replaced with DCP owing to the increase in NDF content (Broderick et al., 2008; Penner \& Oba, 2009). However, there was no subsequent increase in ruminal $\mathrm{pH}$ or in degradability of pasture DM and NDF. Treatment did not affect the acetate : propionate ratio; thus no difference in milk fat content was observed. The SCC for cows on the NDCP treatment was about half of that of those on the LDCP, MDCP and HDCP treatments. However, this was not physiologically significant as it was well under the current legal standard of $<500 \times 10^{3}$ cells $/ \mathrm{mL}$ (Petzer et al., 2017) and is indicative of good udder health. The quadratic effects on milk protein and milk lactose content for cows in the LDCP and MDCP treatments could indicate possible associative effects between multiple feed components (Doyle et al., 2005). In a study by Higgs et al. (2013), a decrease in milk protein was found for cows that 
received molasses as the only supplement to pasture, compared with those that received high maize-based concentrate supplements. This decrease in milk protein is probably because of a lack of NFC in the diet, lowering the ability of ruminal microbes to utilize $\mathrm{N}$ from pasture (Heldt et al., 1999; McCormick et al., 2001). The ruminal $\mathrm{NH}_{3}-\mathrm{N}$ concentration in the LDCP and MDCP treatments was not known. However, it could be assumed that it would not have been high owing to the efficient incorporation into microbial protein. Treatment had no effect on BW gain, BCS change or ADG. However, there was an improvement in BCS for cows in all treatments, and all cows gained weight. This suggests that the concentrate supplements were sufficient to maintain and slightly improve the BCS of cows in early to mid lactation.

An increase in ruminal $\mathrm{pH}$ and more time spent above $\mathrm{pH} 5.8$ were expected, but not found. Pectin is degraded rapidly in the rumen, but it differs from starch in that it is not fermented to lactate and does not contribute as much to the decline in ruminal pH (Strobel \& Russell, 1986; Bampidis \& Robinson, 2006). Pectin fermentation ceases under low ruminal $\mathrm{pH}$, and there is no cumulative effect of lowered ruminal $\mathrm{pH}$ (Strobel \& Russell, 1986; Allen, 2001). Sugar provides less carbon for VFA production per unit of mass compared with starch (Hall \& Herejk, 2001) and increases the passage rate and production of MP (Sutoh et al., 1996; Ribeiro et al., 2005), essentially providing less OM for fermentation. Furthermore, rumen microorganisms are able to convert sucrose to glycogen for short-term energy storage (Hall \& Weimer, 2007), temporarily reducing VFA production in the rumen (Oba, 2011) and thereby minimizing the potential negative effect on ruminal $\mathrm{pH}$. The higher NDF content of the HDCP concentrate supplement could also be expected to contribute to a higher ruminal $\mathrm{pH}$. However, this NDF is not physically effective and does not help stimulate rumination and salivation.

No response on total VFA concentration was found when maize was replaced with DCP, which is similar to in vivo results reported in previous studies (Khalili \& Huhtanen, 1991; Chamberlain et al., 1993, Leiva et al., 2000; Sannes et al., 2002). No change in the acetate and butyrate concentration as the sugar inclusion was increased corresponds with the milk fat content, which was also similar between the NDCP and HDCP treatments. The propionate concentration was not different between the NDCP and HDCP treatments, and does not provide an explanation for the decrease in milk yield when maize was replaced with DCP. Increased levels of sugar in the diet have been shown to decrease the acetate concentration (Khalili \& Huhtanen, 1991; Chamberlain et al., 1993; Broderick et al., 2008), increase butyrate concentration (Khalili \& Huhtanen, 1991, Chamberlain et al., 1993) and result in no change in acetate concentration or the acetate: propionate ratio (Khalili \& Huhtanen, 1991; Leiva et al., 2000; Oelker et al., 2009). In theory, the replacement of maize with DCP should lead to a change in the VFA profile of the rumen. However, effects are confusing and no clear trend could be identified from previous literature. Cows in the NDCP treatment had a higher concentration of isobutyrate and isovalerate than those in the HDCP treatment, similar to Khalili \& Huhtanen (1991). Branched chain volatile fatty acids (BCVFA) are essential for the effective functioning of cellulolytic bacteria and the synthesis of microbial protein, specifically the amino acids valine, isoleucine, leucine and proline (Cummins \& Papas, 1985; Andries et al., 1987). Broderick et al. (2008) found a decrease in total BCVFA concentration as the level of sugar in the diet increased.

The concentration of $\mathrm{NH}_{3}-\mathrm{N}$ is dependent on how efficiently ruminal microbes are able to utilize the $\mathrm{N}$ from $\mathrm{NH}_{3}-\mathrm{N}$ for microbial protein production. This is determined by the availability of the energy source (Bach et al., 1999; Heldt et al., 1999; Higgs et al., 2013). The NDCP concentrate supplement had a higher NFC content than the HDCP, thus the ability of microbes of cows on the HDCP treatment to utilize the N from ruminal $\mathrm{NH}_{3}-\mathrm{N}$ could have been limited by the availability of NFC. There was no difference in milk protein content between the NDCP and HDCP concentrate supplements, thus there was no indication of improved utilization of $\mathrm{NH}_{3}-\mathrm{N}$ by ruminal microbes. The CP content of the HDCP concentrate supplement was slightly higher than that of the NDCP and could have contributed to the higher ruminal $\mathrm{NH}_{3}-\mathrm{N}$ concentration. Cows in the HDCP treatment had a tendency towards higher MUN content, which could be indicative of an oversupply of $\mathrm{NH}_{3}-\mathrm{N}$ in the rumen (Jonker et al., 1998). However, the MUN content of all four treatments was within the normal acceptable range of 8-12 mg/dL (Kohn, 2007), and the trend does not hold much biological significance. The daily ruminal $\mathrm{NH}_{3}-\mathrm{N}$ concentration was higher for cows in the HDCP treatment. However, these values fall within the accepted range of $8.7-32.2 \mathrm{mg} / \mathrm{dL}$ (Bargo et al., 2003). It could be postulated that the decrease in milk yield as the level of DCP inclusion increased, which corresponded to an increase in soybean oilcake inclusion, could be owing to an oversupply of protein, with energy being diverted to deal with the excess protein supply instead of being used for milk production (Broderick, 2003). The CP content of the four experimental diets ranged from 117 to $121 \mathrm{~g} / \mathrm{kg}$ DM. However, the protein fractions (rumen undegradable protein, rumen degradable protein and amino acids) were not investigated and were beyond the scope of this study. Many complex interrelationships play a role here and were not a focus of the study.

An improvement in pasture degradability was expected for cows in the HDCP treatment. However, no 
improvement was found in ruminal $\mathrm{pH}$, and thus no improvement in pasture degradability. A higher mean ruminal $\mathrm{pH}$ with fewer and shorter dips below pH 6.0 would promote cellulolytic bacteria activity, increasing the degradability of pasture (Calsamiglia et al., 2002; Jacobs, 2014). Earlier results of the effect of increasing sugar and pectin content on NDF degradability of roughages varied, with some studies finding no improvement (Penner \& Oba, 2009) and others finding linear and quadratic effects (Broderick \& Radloff, 2004; Broderick et al., 2008). Previous in vitro studies found that the use of molasses as a substrate increased the DM degradability of ryegrass pasture. However, ryegrass pasture NDF degradability remained unchanged (Malan, 2009) and the use of sucrose and pectin as a substrate led to linear and quadratic increases in NDF digestion at 24 hours of incubation, respectively (Holtshausen, 2004). Improved pasture DM and NDF degradability could increase pasture DMI, promoting a more stable rumen environment and increasing production. The lack of response in pasture DM and NDF degradability should be investigated.

\section{Conclusion}

Replacing maize with DCP caused a decrease in milk yield and 4\% FCM yield. Milk protein and milk lactose content were not affected. Rumen health and activity were maintained, and no improvement was observed. The use of DCP as a replacement for maize in a concentrate supplement fed to Jersey cows grazing ryegrass pasture should be considered only if DCP is available at a lower cost than maize, making up for the decrease in income over feed cost because of a possible decrease in milk production.

\section{Acknowledgements}

The authors are thankful to the Western Cape Agricultural Research Trust for funding the project. The financial assistance of the National Research Foundation (NRF) towards this research is acknowledged. Opinions expressed and conclusions arrived at are those of the authors and are not necessarily to be attributed to the NRF. The authors are grateful to the staff at Outeniqua Research farm for their support during the trial.

\section{Authors' Contributions}

All co-authors participated in project design and in the interpretation of the study. LS was in charge of project implementation and writing the manuscript.

\section{Conflict of Interest Declaration}

The authors wish to confirm that no known conflicts of interest are associated with the publication of this manuscript and there has been no significant financial support for this work that could have influenced its outcome. They also confirm that this manuscript has been read and approved by all authors and that the order of authors listed in the manuscript was approved by all of them.

\section{References}

Agricultural Research Council (ARC), 2013. Agro-climatology database. ARC Institute for Soil, Climate and Water, Department of Agro-Climatology. I.O. van Gent, vgenti@arc.agric.za, Stellenbosch.

Allen, M.S., 2001. Formulating lactating cow diets for carbohydrates. In: Proc. 5th Western Dairy Management Conference, pp. 79-86.

Allen, M.S. \& Knowlton, F., 1995. Non-structural carbohydrates important for ruminants. Feedstuffs 17: 13-15.

Andries, J.I., Buysse, F.X., De Brabander, D.L. \& Cottyn, B.G., 1987. Isoacids in ruminant nutrition: Their role in ruminal and intermediary metabolism and possible influences on performance, a review. Anim. Feed Sci. Technol. 18: $169-180$.

AOAC International, 2002. Official methods of analysis. 17th ed. Assoc. Off. Anal. Chem., Arlington, VA, USA.

Bach, A., Yoon, I.K., Stern, M.D., Jung, H.G. \& Chester-Jones, H., 1999. Effects of type of carbohydrate supplementation to lush pasture on microbial fermentation in continuous culture. J. Dairy Sci. 82: 153-160.

Bampidis, V.A. \& Robinson, P.H., 2006. Citrus by-products as ruminant feeds: A review. Anim. Feed Sci. Technol. 128: 175-217. doi:10.1016/j.anifeedsci.2005.12.002.

Bargo, F., Muller, L.D., Kolver, E.S. \& Delahoy, J.E., 2003. Invited review: Production and digestion of supplemented dairy cows on pasture. J. Dairy Sci. 86: 1-42.

Broderick, G.A., 2003. Effects of varying dietary protein and energy levels on the production of lactating dairy cows. J. Dairy Sci. 86:1370-1381.

Broderick, G.A. \& Kang, J.H., 1980. Automated simultaneous determination of ammonia and total amino acids in ruminal fluid and in vitro media. J. Dairy Sci. 63: 64-75.

Broderick, G.A. \& Radloff, W.J., 2004. Effect of molasses supplementation on the production of lactating dairy cows fed diets based on alfalfa and corn silage. J. Dairy Sci. 87: 2997-3009.

Broderick, G.A., Luchini, N.D., Reynal, S.M., Varga, G.A. \& Ishler, V.A., 2008. Effect on production of replacing dietary starch with sucrose in lactating dairy cows. J. Dairy Sci. 91: 4801-4810. Doi:10.3168/jds.2008-1480.

Buys, A.J., Van Vuuren, J.A.J., Coetzee, J.G.K., Claasens, A.S. \& Barnard, R.O., 1996. ALASA: Agricultural Laboratory Association of Southern Africa - Ensuring reliable analyses. Commun. Soil Sci. Plant Anal. 27: 1571-1578.

Calsamiglia, S., Ferret, A. \& Devant, M., 2002. Effects of $\mathrm{pH}$ and pH fluctuations on microbial fermentation and nutrient flow from a dual-flow continuous culture system. J. Dairy Sci. 85: 574-579.

Calsamiglia, S., Ferret, A., Reynolds, C.K., Kristensen, N.B. \& Van Vuuren, A.M., 2010. Strategies for optimizing nitrogen 
use by ruminants. Anim. 4: 1184-1196. Doi:10.1017/S1751731110000911.

Chamberlain, D.G., Robertson, S. \& Choung, J.J., 1993. Sugars versus starch as supplements to grass silage: Effects on ruminal fermentation and the supply of microbial protein to the small intestine, estimated from urinary excretion of purine derivatives, in sheep. J. Sci. Food Agr. 63: 189-194.

Cherney, D.J.R., Cherney, J.H. \& Chase, L.E., 2003. Influence of dietary non-fibre carbohydrate concentration and supplementation of sucrose on lactation performance of cows fed fescue silage. J. Dairy Sci. 86: 3983-3991.

Cummins, K.A. \& Papas, A.H., 1985. Effect of isocarbon-4 and isocarbon-5 volatile fatty acids on microbial protein synthesis and dry matter digestibility in vitro. J. Dairy Sci. 68: 2588-2595.

Delahoy, J.E., Muller, L.D., Bargo, F., Cassidy, T.W. \& Holden, L.A., 2003. Supplemental carbohydrate sources for lactating dairy cows on pasture. J. Dairy Sci. 86: 906-915.

Doyle, P.T., Francis, S.A. \& Stockdale, C.R., 2005. Associative effects between feeds when concentrates supplements are fed to grazing dairy cows: A review of likely impacts on metabolisable energy supply. Aust. J. Agr. Res. 56, 1315-1329. Doi: 10.1071/AR05087.

Edmonson, A.J., Lean, I.J., Weaver, L.D., Farver, T. \& Webster, G., 1989. A body condition scoring chart for Holstein dairy cows. J. Dairy Sci. 72(1): 68-78.

Gaines, W.L., 1928. The energy basis of measuring milk yield in dairy cows. Uni. of Illinois, Agric. Exp. Station, Bulletin 308.

Hall, M.B. \& Herejk, C., 2001. Differences in yields of microbial crude protein from in vitro fermentation of carbohydrates. J. Dairy Sci. 84: 2486-2493.

Hall, M.B. \& Weimer, P.J., 2007. Sucrose concentration alters fermentation kinetics, products and carbon fates during in vitro fermentation with mixed ruminal microbes. J. Anim. Sci. 85: 1467-1478. Doi: 10.2527/jas.2006-014.

Heldt, J.S., Cochran, R.C., Mathis, C.P., Woods, B.C., Olson, K.C., Titgemeyer, E.C., Nagaraja, T.G., Vanzant, E.S. \& Johnson, D.E., 1999. Effects of level and source of carbohydrates and level of degradable intake protein on intake and digestion of low-quality tallgrass prairie hay by beef steers. J. Anim. Sci. 77: 2846-2854.

Higgs, R.J., Sheahan, A.J., Mandok, K., Van Amburgh, M.E. \& Roche, J.R., 2013. The effect of starch-, fibre-, or sugarbased supplements on nitrogen utilisation in grazing dairy cows. J. Dairy Sci. 96: 3857-3866. Doi:10.3168/jds.2012-6117.

Hindrichsen, I.K., Wettstein, H.R., Machmüller, A., Soliva, C.R., Bach Knudsen, K.E., Madsen, J. \& Kreuzer, M., 2004. Effects of feed carbohydrates with contrasting properties on rumen fermentation and methane release in vitro. Can. J. Anim. Sci. 84: 265-276.

Holtshausen, L., 2004. Effect of non-fibre carbohydrates on product yield and fibre digestion in fermentations with mixed ruminal microbes. PhD dissertation, University of Florida, FL, USA.

Irvine, L.D., Freeman, M.J. \& Rawnsley, R.P., 2010. The effect of grazing residual control methods on cow intake and milk production in late spring. In: of the fourth Australasian Dairy Science Symposium, pp. 195-198.

Jacobs, J.L., 2014. Challenges in ration formulation in pasture-based milk production systems. Anim. Prod. Sci. 54: 1130-1140. Doi:10.1071/AN14463.

Jonker, J.S., Kohn, R.A. \& Erdman, R.A., 1998. Using milk urea nitrogen to predict nitrogen excretion and utilisation efficiency in lactating dairy cows. J. Dairy Sci. 81: 2681-2692.

Khalili, H. \& Huhtanen, P., 1991. Sucrose supplements in cattle given grass silage based diet. 1. Digestion of organic matter and nitrogen. Anim. Feed Sci. Technol. 33: 247-261.

Kohn, R., 2007. Use of milk or blood urea nitrogen to identify feed management inefficiencies and estimate nitrogen excretion by dairy cattle and other animals. Florida Ruminant Nutr. Symposium, Gainesville, FL.

Leiva, E., Hall, M.B. \& Van Horn, H.H., 2000. Performance of dairy cattle fed citrus pulp or corn products as sources of neutral detergent-soluble carbohydrates. J. Dairy Sci. 83: 2866-2875.

Malan, M., 2009. The effect of sugar, starch and pectin as microbial energy source on in vitro forage fermentation kinetics. M.Sc. (Agric) thesis. Stellenbosch University, South Africa.

McCormick, M.E., Redfearn, D.D., Ward, J.D. \& Blouin, D.C., 2001. Effect of protein source and soluble carbohydrate addition on rumen fermentation and lactation performance of Holstein cows. J. Dairy Sci. 84: 1686-1697.

Miller-Webster, T.K. \& Hoover, W.H., 1998. Nutrient analysis of feedstuffs including carbohydrates. Anim. Sci. Report No. 1, West Virginia Uni.

National Research Council, 2001. Nutrient requirements of dairy cattle. 7th rev. ed. Natl. Acad. Press, Washington, D.C.

Oba, M., 2011. Review: Effects of feeding sugars on productivity of lactating dairy cows. Can. J. Anim. Sci. 91: 37-46. Doi:10.4141/CJAS10069.

Oelker, E.R., Reveneau, C. \& Firkins, J.L., 2009. Interaction of molasses and monensin in alfalfa hay or corn silage based diets on rumen fermentation, total tract digestibility, and milk production by Holstein cows. J. Dairy Sci. 92 : 270-285. Doi:10.3168/jds.2008-1432.

Ørskov, E.R. \& McDonald, I., 1979. The estimation of protein degradability in the rumen from incubation measurements weighted according to rate of passage. J. Agric. Sci. Camb. 92: 499-503.

Penner, G.B. \& Oba, M., 2009. Increasing dietary sugar concentration may improve dry matter intake, ruminal fermentation, and productivity of dairy cows in the postpartum phase of the transition period. J. Dairy Sci. 92: 3341-3353. Doi:10.3168/jds.2008-1977.

Petzer, I-M., Karzis, J., Donkin, E.F., Webb, E.C. \& Etter, E.M.C., 2017. Somatic cell count thresholds in composite and quarter milk samples as indicator of bovine intramammary infection status. Onderstepoort J. Vet. 84: 1-10. Doi: 
10.4102/ojvr.v84i1.1269.

Poulsen, M., Jensen, B.B. \& Engberg, R.M., 2012. The effect of pectin, corn and wheat starch, inulin and $\mathrm{pH}$ on the in vitro production of methane, short chain fatty acids and on the microbial community composition in rumen fluid. Anaerobe 18: 83-90. Doi:10.1016/j.anaerobe.2011.12.009.

Ribeiro, C.V.D.M., Karnati, S.K.R. \& Eastridge, M.L., 2005. Biohydrogenation of fatty acids and digestibility of fresh alfalfa or alfalfa hay plus sucrose in continuous culture. J. Dairy Sci. 88: 4007-4017.

Robertson, J.B. \& Van Soest, P.J., 1981. The detergent system of analysis and its application to human foods. In: W.P.T. James \& O. Theander (eds). Basic and clinical nutrition vol. 3. The analysis of dietary fibre in foods. Dekker, N.Y. pp. 158-276.

Robinson, P.H., Givens, D.I. \& Getachew, G., 2004. Evaluation of National Research Council, UC Davis and ADAS approaches to estimate the metabolisable energy values of feeds at maintenance energy intake from equations utilising chemical assays and in vitro determinations. Anim. Feed Sci. Technol. 114: 75-90. Doi:10.1016/j.anifeedsci.2003.12.002.

Sannes, R.A., Messman, M.A. \& Vagnoni, D.B., 2002. Form of rumen-degradable carbohydrates and nitrogen on microbial protein synthesis and protein efficiency of dairy cows. J. Dairy Sci. 85: 900-908.

SAS Institute, Inc. 2008. SAS Version 9.2., SAS Campus Drive, Cary, North Carolina 27513

Shapiro, S.S. \& Wilk, M.B., 1965. An analysis of variance test for normality (complete samples). Biometrika 52: 591-611.

Siegfried, V.R., Ruckermann, H. \& Stumpf, G., 1984. Method for the determination of organic acids in silage by high performance liquid chromatography. Landwirtsch. Forschung 37: 298-304.

Steyn, L., 2012. Supplementation of high fibre concentrate to Jersey cows on pasture to overcome winter roughage shortages. M.Sc.(Agric) thesis, Stellenbosch University, South Africa.

Strobel, H.J. \& Russell, J.B., 1986. Effect of $\mathrm{pH}$ and energy spilling on bacterial protein synthesis by carbohydrate limited cultures of mixed rumen bacteria. J. Dairy Sci. 69: 2941-2947.

Sutoh, M., Obara, Y. \& Miyamoto, S., 1996. The effect of sucrose supplementation on kinetics of nitrogen, ruminal propionate and plasma glucose in sheep. J. Agr. Sci. 126: 99-105.

Swanepoel, P.A., Botha, P.R., Du Preez C.C. \& Snyman, H.A., 2013. Physical quality of a podzolic soil following 19 years of irrigated minimum-till kikuyu-ryegrass pasture. Soil Tillage Res. 133: 10-15. Doi: 10.1016/j.still.2013.05.008.

Wildman, E.E., Jones, G.M., Wagner, P.E., Boman, R.L., Troutt Jr, H.F. \& Lesch, T.N., 1982. A dairy cow body condition scoring system and its relationship to selected production characteristics. J. Dairy Sci. 65(3): 495-501. 